\title{
UJI AKTIFITAS ANTI BAKTERI EKSTRAK RIMPANG JAHE TERHADAP E.colli SECARA IN VITRO MELALUI MODEL PBL
}

\author{
Lukas Seran*1, Rikardus Herak $^{2}$ \\ ${ }^{1,2}$ Program Studi Pendidikan Biologi, FKIP, Universitas Katolik Widya Mandira, Kupang, Indonesia \\ e-mail: ${ }^{1}$ lukasseran08@gmail.com, ${ }^{2}$ herakricky@gmail.com
}

\begin{abstract}
ABSTRAK
Bakteri E. Colli merupakan salah satu bakteri patogenik opertunistik yang dapat resisten bila terpapar obat-obatan sintetik secara tidak teratur. Oleh karena itu penemuan obat-obatan baru harus terus dilakukan. Sumber potensial obat-obatan baru yaitu bahan alam herbal yang secara tradisional dipakai oleh masyarakat untuk menyembuhkan penyakit secara tradisional pula. Jahe secara tradisional dipakai sebagai obat untuk menyembuhkan penyakit diare. Tujuan penelitian ini adalah untuk membuktikan secara ilmiah kasiat jahe dalam menyembuhkan penyakit diare melalui indikator anti bakteri secara In Vitro.Penelitian ini merupakaneksperimen sungguhan (thrue eksperiment) yang dikembangkan dari PBL. Penelitian ini dilaksanakan di Laboratorium Mikrobiologi Universitas Katolik Widya Mandira oleh mahasiswa semester VI,dengan menggunakan The Post Test Only Control Group Design dengan 4 perlakuan $(\mathrm{P})$ dimana $\mathrm{P} 1=25 \%, \mathrm{P} 2=50 \%, \mathrm{P} 3=75 \%, \mathrm{P} 4=100 \%$, dan kontrol dengan konsentrasi $0 \%$. Perlakuan diulang sebanyak 3 kali. Bukti ada tidaknya kemampuan anti bakteri terlihat dari ada tidaknya dan luas semptnya zona hambat pada media pertumbuhan. Hasil penelitian menunjukkan bahwa ekstrak rimpang jahe efektif sebagai anti bakteri dibuktikan dengan $F_{\text {hitung }}>F_{\text {tabel }}(\mathbf{1 1 0 . 6 7 8 3 6 3}>$ 7,59) yakni dengan tingkat kepercayaan $99 \%$ dan efektifitas anti bakteri terbesar terjadi pada konsentrasi $100 \%$ yang dibuktikan dengan luas zona hambat $18.48 \mathrm{~mm}$.
\end{abstract}

Kata Kunci: Rimpang Jahe, anti bakteri, E. colli

\section{ABSTRACT}

Bacteria E. Colli is one of the opertunistic pathogenic bacteria that can be resistant when exposed to synthetic drugs on an irregular basis. Therefore the discovery of new medicines must continue. Potential sources of new medicines are herbal natural ingredients that are traditionally used by people to cure diseases traditionally as well. Ginger is traditionally used as a medicine to cure diarrhea. The purpose of this study is to scientifically prove the efficacy of ginger in curing diarrheal diseases through anti-bacterial indicators in vitro. This research is a real experiment (thrue experiment) developed from PBL. This research was conducted in the Microbiology Laboratory of Widya Mandira Catholic University by semester VI students, using The Post Test Only Control Group Design with 4 treatments $(P)$ where $P 1=25 \%, P 2=$ $50 \%, P 3=75 \%, P 4=100 \%$, and control with a concentration of $0 \%$. The treatment was repeated 3 times. Evidence of the presence or absence of anti-bacterial ability can be seen from the presence or absence and extent of inhibitory zones in growth media. The results showed that the effective ginger rhizome extract as an antibacterial was proven by $F_{-}$hitung $>F_{-}$(table) $(110.678363>7.59)$ ie with a 99\% confidence level and the greatest anti-bacterial effectiveness occurred at $100 \%$ concentration as evidenced by the inhibition zone area of $18.48 \mathrm{~mm}$

Keyword: Ginger Rhizome, anti-bacterial, E. colli 


\section{PENDAHULUAN}

Kesehatan merupakan hak dan investasi bagi semua warga negara Indonesia. Hak atas kesehatan ini dilindungi oleh konstitusi, seperti: tercantum dalam UUD 1945, Pasal 27 ayat kedua dimana tiap-tiap warga negara berhak atas pekerjaan dan penghidupan yang layak bagi kemanusiaan. Berpijak pada hal di atas, maka semua warga negara tanpa kecuali mempunyai hak yang sama dalam penghidupan, kesehatan dan pekerjaan.

Kesehatan merupakan modal dasar yang sangat diperlukan oleh segenap masyarakat untuk dapat beraktifitas sesuai dengan tugas dan tanggung jawabnya masing-masing, sehingga mampu menghasilkan sesuatu yang bermanfaat bagi diri sendiri dan keluarga. Namun bila kondisi kesehatan bermasalah bukan tidak mungkin seluruh harta dan kekayaan akan habis digunakan untuk memperoleh kesehatan tersebut.

Masalah kesehatan merupakan masalah kompleks yang merupakan resultan dari berbagai masalah lingkungan yang bersifat alamiah maupun masalah buatan manusia. Cara hidup dan gaya hidup manusia merupakan fenomena yang dapat dikaitkan dengan munculnya berbagai macam penyakit. Salah satu adalah penyakit diare. Diare merupakan salah satu penyakit dengan insidensi tinggi di dunia dan dilaporkan terdapat hampir 1,7 milyar kasus setiap tahunnya. Penyakit ini sering menyebabkan kematian pada anak usia di bawah lima tahun (balita). Dalam satu tahun sekitar 760.000 anak usia balita meninggal karena penyakit.

Diare masih menjadi masalah kesehatan masyarakat di negara berkembang seperti Indonesia karena memiliki insidensi dan mortalitas yang tinggi. Penyebab diare dapat dipicu oleh beberapa hal antara lain: alergi makanan, penyakit usus, radang pada saluran pencernaan, infeksi virus dan bakteri. Diperkirakan 20-50 kejadian diare per 100 penduduk setiap tahunnya. Kematian terutama disebabkan karena penderita mengalami dehidrasi berat. 70$80 \%$ penderita adalah mereka yang berusia balita. Menurut data Departemen
Kesehatan, diare merupakan penyakit kedua di Indonesia yang dapat menyebabkan kematian anak usia balita setelah radang paru atau pneumonia (Yanda, RF. 2014). Salah satu penyebab penyakit diare adalah kurangnya kesadaran masayarakat akan kebersihan makanan dan air.

Kontrol penyakit diare sendiri telah lama diupayakan oleh pemerintah Indonesia untuk penekanan angka kejadian diare. Upaya-upaya yang dilakukan oleh pemerintah seperti adanya programprogram penyediaan air bersih dan sanitasi total berbasis masyarakat, memberikan pendidikan kesehatan spesifik dengan tujuan bisa meningkatkan kualitas hidup masyarakat dan menurunkan kematian yang disebabkan oleh penyakit diare serta menyediakan obat-obat medis sepeti loporamide, bismutch subsaliclatylate, attapulgite. Baik dalam bentuk kapsul, tablet ataupun obat cair. Penggunaan obat medis memang dapat menyembuhkan penyakit diare, namun disatu sisi menimbulkan efek samping dan menyebabkan penyakit lain.

Oleh karena banyak masyarakat yang mulai sadar, dan kembali menggunakan tanaman herbal yang dijadikan obat dalam mengatasi berbagai penyakit, seperti menggunakan jahe untuk mengobati penyakit diare. Masyarakat Manggarai, NTT sudah lama menggunakan jahe sebagai obat yang memiliki khasiat dalam menyembuhkan penyakit diare. Selain itu proses pengolahan tidak membutuhkan waktu yang lama dan mengeluarkan biaya. Cara yang dipakai sangat mudah yakni jahe diparut kemudian direndam dalam air panas \pm 30 menit. Kemudian air jahe tersebut diminum. Cara ini ternyata membuahkan hasil, karena mampu mengatasi penyakit diare. Berdasarkan uraian diatas,maka peneliti terdorong untuk melakuan penelitian:

Pelaksanaan penelitian ini menggunakan model pembelajaran berbasis masalah atau problem based learning. Dalam pembelajaran Dosen dan mahasiswa berkesempatan untuk menerapkan keterampilan yang dimiliki sehingga dapat 
merumuskan dan menyelesaikan masalah yang dihadapi. Pembelajaran berbasis masalah merupakan sebuah pendekatan yang menyajikan masalah kontekstual sehingga merangsang mahasiswa untuk belajar. Dengan menerapkan pembelajaran berbasis masalah, mahasiswa bekerja dalam tim untuk memecahkan masalah dunia nyata.

\section{METODE}

Penelitian ini merupakan eksperimen sungguhan (thrue eksperiment). Penelitian ini dilaksanakan di Laboratorium Mikrobiologi Universitas Katolik Widya Mandira. Penelitian ini menggunakan desain The Post Test Only Control Group Designdengan 4 perlakuan dan1 kontrol. Dimana konsentrasi $\mathrm{P} 1=25 \%, \mathrm{P} 2=50 \%$, $\mathrm{P} 3=75 \%$, P4=100\%, yang akan diulang sebanyak 3 kali ulangan, serta aquades sebagai kontrol.

Tahapan Penelitian ini sebagai berikut:1) Tahap persiapan (Sterilisasi alat, pembuatan media Natrium Agar (NA), Sterilisasi media) 2)Menyiapkan bahan uji (persiapan sampel, rimpang Jahe (Zingiber officinale rosc) dibersihkan kemudian dihaluskan dengan menggunakan alat penghalus atau dibelender, pembuatan konsentrasi 25\% 50\%, 75\%, dan 100\%), 3) Tahap persiapan bakteri uji Escherichia coli (peremajaan biakan murni, membuat seri pengenceran, tahap uji antibakteria). Teknik pengambilan data dengan mengukur besarnya zona bening ekstrak rimpang jahe (Zingiber officinale rosc) dalam menghambat bakteri Escherichia coli adalah dengan cara mengukur zona bening (zona dimana terjadinya penghambatan pertumbuhan bakteri) yang terbentuk oleh kemampuan anti bakteri oleh ekstrak pada media yang telah diinkubasi selama 24 jam dengan menggunakan jangka sorong.Sedangkan untuk mengumpulkan data keterampilan proses para subyek penelitian (Mahasiswa semester VI Program Studi Pendidikan Biologi Universitas Katolik Widya Mandira), maka digunakan instrument berupa rubrik keterampilan proses.

Teknik analisa data dengan analisis varians (ANAVA) satu arah. Anava bertujuan untuk mengetahui ada tidaknya kemampuan antibakteri ekstrak rimpang jahe (Zingiber officinale rosc) terhadap pertumbuhan bakteri Escherichia coli dan apabila terdapat perbedaan yang signifikan maka dilanjutkan dengan Uji Beda Nyata Terkecil (BNT) dengan tingkat signifikan $1 \%(0,01)$.

\section{HASIL DAN PEMBAHASAN}

1. Hasil Uji Ekstrak Rimpang Jahe (Zingiber officinale rosc)

Berdasarkan uji aktivitas antibakteri ekstrak rimpang Jahe (Zingiber officinale rosc) terhadap pertumbuhan bakteri Escherichia coli secara in-vitroselama 24 jam menunjukan bahwa adanya zona hambat yang terbentuk pada kertas cakram. Hasil selengkapnya dapat dilihat pada tabel 1 berikut :

\section{Tabel 1. Hasil Pengukuran Zona Hambat Bakteri Escherichia coli}

\begin{tabular}{ccccccc}
\hline No. & $\begin{array}{c}\text { Konsentrasi } \\
\text { Larutan Uji }\end{array}$ & I & II & III & $\begin{array}{c}\text { Jumlah } \\
(\mathrm{mm})\end{array}$ & $\begin{array}{c}\text { Rata-rata } \\
(\mathrm{mm})\end{array}$ \\
\hline 1 & $0 \%$ & 0 & 0 & 0 & 0 & 0 \\
2 & $25 \%$ & 0 & 0 & 0 & 0 & 0 \\
3 & $50 \%$ & 1,65 & 7,37 & 8,24 & 27,26 & 9,086 \\
4 & $75 \%$ & 3,48 & 11,6 & 3,48 & 38,56 & 12,853 \\
5 & $100 \%$ & 18 & 8,46 & 8,98 & 55,44 & 18,48 \\
\hline
\end{tabular}

Keterangan : Pengukuran dilakukan dengan menggunakan jangka sorong dimulai dari tepi kertas cakram hingga tepi ujung zona bening yang terbentuk. 
Tabel 1 menunjukan bahwa adanya salah satu konsentrasi yang tidak menunjukan adanya zona hambat pada pertumbuhan bakteri Escherichia coliyaitu pada konsentrasi $25 \%$, sedangkan pada konsentrasi $50 \%, \quad 75 \%$ dan $100 \%$ menunjukan bahwa adanya pertumbuhan bakteri Escherichia coli. Apabila zat antibakteri bersifat menghambat atau membunuh bakteri tersebut maka pertumbuhan bakteri akan terhenti didaerah sekitar kertas cakram yang ditandai dengan zona bening disekitar kertas cakram. Dapat dilihat pada gambar 1 berikut :
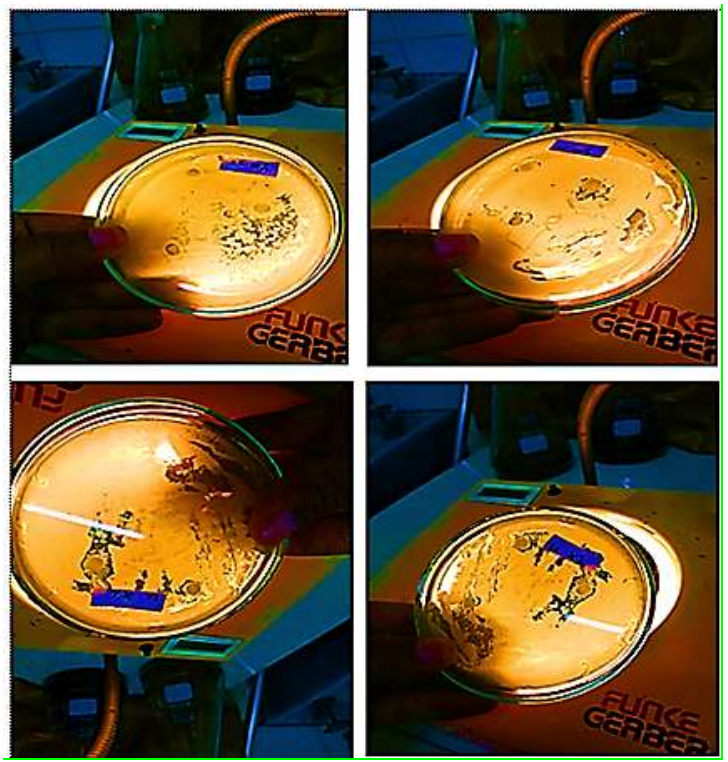

Gambar 1. Hasil Uji Efektivitas Antibakteri Ekstrak Rimpang Jahe (Zingiber officinale rocs)

Gambar 1 memperlihatkan hasil pengukuran dari aktivitas antibakteri jelas memperlihatkan hasil pengukuran aktivitas antibakteri jelas memperlihatkan adanya zona hambat (zona bening) yang terbentuk setelah diinkubasi selama 24 jam dengan rerata yang berbeda pada setiap perlakuan ekstrak jahe (Zingiber officinale rocs)sebagai berikut, 1) Pada kontrol negative $(0 \%)$ tidak terjadi zona hambat pada kertas cakram, 2) Pada konsentrasi $(25 \%)$ tidak terjadi zona hambat pada kertas cakram, 3) Pada konsentrasi (50\%) terjadi zona hambat mencapai rata-rata $9.086 \mathrm{~mm}$ pada media kertas cakram, 4) Pada konsenrasi $(75 \%)$ terjadi zona hambat mencapai rata-rata $12.853 \mathrm{~mm}$ pada media kertas cakram dan 5) Pada konsentrasi
$(100 \%)$ terjadi zona hambat mencapai ratarata $18.48 \mathrm{~mm}$ pada media kertas cakram.

Pengolahan data yang sudah diperoleh dalam mengukur zona hambat pada tabel 1 dianalisis dengan teknik perhitungan yang disebut Analisis Varian (ANAVA). Teknik perhitungan dilakukan untuk mengetahui ada tidaknya pengaruh ekstrak rimpang Jahe (Zingiber officinale rocs) terhadap pertumbuhan bakteri Escherichia coli dengan tingkat signifikan $(0,01)$.
a. Menentukan
Derajat
Bebas
Perlakuan (DB)
1. DB Total $=(t, r)-1$
2. Derajat Bebas Perlakuan $=\mathrm{t}-1$
3. Derajat Beas Galat $=\mathrm{DBT}-\mathrm{DBP}$

b. Menentukan Faktor Koreksi (FK) 


$$
F K=\frac{T_{i} j^{2}}{r \cdot t}
$$

c. Menentukan Jumlah Kuadrat (JK)

1. Jumlah Kuadrat Total (JKT)

$$
\mathrm{JKT}=\left(P_{1}\right)^{2}+\cdots\left(P_{n}\right)^{2}-F K
$$

2. Jumlah Kuadrat Perlakuan (JKP)

$$
J K P=\frac{(T A)^{2}+(T B)^{2}+(T C)^{2}+\ldots+(T V)^{2}}{-F K}
$$

3. Kuadrat Galat $(\mathrm{JKG})=\mathrm{JKT}-\mathrm{JK}$

\section{d. Menghitung Kuadrat Tengah (KT)}

1. Kuadrat Tengah Perlakuan (KTP)

$$
K T P=\frac{J K P}{D B P}
$$

2. Kuadrat Tengah Galat (KTG)

$$
K T G=\frac{J K G}{D B G}
$$

\section{e. Menentukan Fhitung}

$$
\text { F hitung }=\frac{K T P}{K T G}
$$

Tabel 2. Hasil Analisis Data

\begin{tabular}{cccccc}
\hline Sumber Variasi & \multirow{2}{*}{$\mathrm{DB}$} & \multirow{2}{*}{$\mathrm{JK}$} & $\mathrm{KT}$ & $\begin{array}{c}\mathrm{F}_{\text {hitung }} \\
00.01\end{array}$ & $\begin{array}{c}\mathrm{F}_{\text {tabel }} \\
00.01\end{array}$ \\
\hline Perlakuan & 3 & 542,53 & 180,84 & 110.678363 & 7,59 \\
Galat & 8 & 13,07 & 1.63339 & & \\
Total & 11 & 555,6 & & & \\
& & & & & \\
\hline
\end{tabular}

Pada Tabel 2 F hitung > F Tabel, menyatakan adanya pengaruh nyata pada setiap konsentrasi ekstrakrimpang Jahe

\begin{tabular}{|c|c|c|c|c|c|c|c|c|}
\hline \multirow{3}{*}{$\begin{array}{l}\text { Konse } \\
\text { ntrasi }\end{array}$} & \multirow{3}{*}{$\begin{array}{l}\text { Perla } \\
\text { kuan }\end{array}$} & \multirow{3}{*}{ Rerata } & \multicolumn{5}{|c|}{ Ulangan } & \multirow{3}{*}{$\begin{array}{l}\text { BNT } \\
1 \% \\
(3,22) \\
\end{array}$} \\
\hline & & & 0 & 1 & 2 & 3 & 4 & \\
\hline & & & 0 & 0 & 9,086 & 12,853 & 18,48 & \\
\hline $0 \%$ & 0 & 0 & Otn & $0 \mathrm{tn}$ & & & & A \\
\hline $25 \%$ & 1 & 0 & Otn & Otn & & & & A \\
\hline $50 \%$ & 2 & 9,086 & $9,086^{*}$ & $9,086^{*}$ & Otn & & & B \\
\hline $75 \%$ & 3 & 12,853 & $12,853^{*}$ & $12,85^{*}$ & $3,767^{*}$ & 0 tn & & C \\
\hline $100 \%$ & 4 & 18,48 & $18,48^{*}$ & $18,48^{*}$ & $9,394 *$ & $5,627^{*}$ & Otn & D \\
\hline
\end{tabular}
(Zingiber officinale rocs), maka dilanjutkan uji BNT Uji Beda Nyata Terkecil (BNT) taraf Sig. $1 \%$

$$
\text { BNT } \alpha=\text { t. } \alpha \sqrt{\frac{2 \mathrm{KTG}}{r}}
$$

Tabel 3. Hasil Uji Lanjut Beda Nyata Terkecil (BNT) Pengaruh Ekstrak Pada Taraf Signifikan $\mathbf{0 , 0 1}$ 


\section{Hasil Penilaian melalui rubrik Keterampilan Proses}

Persentase pencapaianaspek keterampilan proses mahasiswa dalam rubrik adalah sebagai berikut:1) Tahap Pengenalan alat sebesar $92 \%$, 2) Tahap persiapan sampel sebesar 84,11\%, 3) Tahap persiapan bahan uji sebesar 75,55\%, 4) Tahap persiapan bakteri uji sebesar 75,55\% dan 5) Tahap pengambilan data sebesar $74,33 \%$.

\section{PEMBAHASAN}

\section{Uji Ekstrak Rimpang Jahe (Zingiber officinale rocs)}

Berdasarkan hasil penelitian, dapat disimpulkan bahwa terdapat pengaruh konsentrasi ekstrak rimpang Jahe (Zingiber officinale rocs) terhadap pertumbuhan bakteri Escherichia coli. Hal ini ditunjukan dengan adanya zona hambat yang terlihat berbeda dari ke-tiga konsentrasi yang terbentuk pada media Agar Nutrien (NA) yang terlihat berbeda-beda dikarenakan diberi konsentrasi yang berbeda pula yaitu: $75 \%$, dan $100 \%$ yang diukur dengan menggunakan jangka sorong dengan satuan $\mathrm{mm}$. Sedangkan pada konsentrasi $25 \%$ dan $50 \%$ tidak terlihat zona bening yang terbentuk pada media agar tersebut.

Pengaruh yang didapat dikarenakan adanya kandungan zat aktif yang terdapat pada rimpang Jahe (Zingiber officinale rocs) yang mampu menghambat pertumbuhan bakteri Escherichia coli yaitu oleoresin, damar, asam organik, asam malat, asam oksalat, gingerin, gingeron, minyak damar, flavonoid, polifenol, alkaloid, dan musilago yang bersifat antikholinergik. Rimpang Jahe (Zingiber officinale rocs)juga mengandung minyak atsiri jahe dimana terdapat zingiberol, linaloal, kavikol, dan geraniol. Dari eksperimen yang dapat menyatakan bahwa semakin besar konsentrasi yang diberikan maka makin besar konsentrasi yang diberikan maka makin besar pula daya anti bakteri dari rimpang Jahe (Zingiber officinale rocs)atau apabila makin besar konsentrasi maka zona hambat yang paling terbentuk paling besar.
Zona hambat yang terbentuk dikarenakan kemampuan ekstrak rimpang Jahe (Zingiber officinale rocs) sebagai antibakteri dalam menghambat pertumbuhan bakteri. Kemampuan bakteri mampu bertahan hidup dan tidak mampu bertahan hidup, dalam hal ini mampu melawan aktivitas antibakteri yang disebabkan oleh beberapa faktor seperti ketebalan komposisi dan struktur dinding sel pada setiap bakteri. Bakteri gram positif dinding selnya mengandung polisakarida $\&$ protein, Kandungan lipidnya rendah dari pada yang dikandung oleh bakteri gram negative. Dinding sel bakteri gram negative memiliki diding sel yang terdiri atas lipid, lemak atau substansi lemak. Selain itu zona hambat yang dihasilkan juga diakibatkan afektifitas senyawa antibakteri yang dipengaruhi oleh beberapa faktor antara lain konsentrasi, waktu, suhu, dan medium (Wheler, 1993) .

Pada perlakuan konsentrasi 25\% ekstrak tidak mampu menghambat pertumbuhan bakteri Escherichia coli karenamencapai rerata $0 \mathrm{~mm}$. Pada konsentrasi $50 \%$ ekstrak mampu menghambat pertumbuhan bakteri Escherichia coli dengan rerata ukuran zona hambatnya mencapai 9,086 mm. Pada konsentrasi $75 \%$ ekstrak mampu menghambat bakteri Escherichia coli mencapai rerata zona hambatnya 12,853 mm. Sedangkan pada konsentrasi $100 \%$ ukuran zona hambat yang terbentuk semakin meningkat dan yang paling terbesar dan terbaik seiring meningkatnya konsentrasi ekstrak, ukuran zona hambatnya mencapai $18,48 \mathrm{~mm}$. Hal ini didukung oleh pernyataan Prawata dan Dewi (2008), bahwa meningkatnya konsentrasi zat menyebabkan meningkatnya kandungan senyawa aktif yang berfungsi sebagai antibakteri, sehingga kemampuannya dalam menghambat dan membunuh suatu bakteri juga semakin besar.

Dari data pada tabel 3.1 zona hambat aktivitas antibakteri ekstrak rimpang Jahe (Zingiber officinale rocs) terhadap 
pertumbuhan bakteri Escherichia coli yang dianalisis menggunakan analisis varians (ANAVA) taraf signifikan pada tabel 3.2 diatas, maka disimpulkan $F_{\text {hitung }}>F_{\text {tabel }}(\mathbf{1 1 0 . 6 7 8 3 6 3}>\mathbf{7 , 5 9 )}$ yakni dengan tingkat kepercayaan $99 \%$ dengan ini maka adanya pengaruh yang signifikan antara perlakuan konsentrasi ekstrak rimpang Jahe (Zingiber officinale rocs) terhadap bakteri Escherichia coli dapat dilihat juga pada zona hambat kertas cakram.

Pada tabel 3.3 mau menunjukan hasil uji BNT (Beda Nyata Terkecil) dengan tujuan untuk melihat perlakuan dari setiap konsentrasi dari rerata yang ada, maka hasil perhitungan menyatakan bahwa perlakuan konsentrasi $0 \%$ berbeda nyata dengan semua konsentrasi. Konsentasi 25\% berbeda nyata dengan konsentrasi $0 \%$ tetapi tidak berbeda nyata dengan konsentasi $50 \%$, sama halnya dengan konsentrasi $50 \%$ tidak berbeda nyata dengan konsentrasi $25 \%$ dan juga tidak berbeda nyata dengan konsentrasi $75 \%$, sama halnya juga dengan konsentrasi $75 \%$ tidak berbeda nyata dengan konsentrasi $50 \%$ juga tidak berbeda nyata dengan konsentrasi $100 \%$, dan konsentrasi $100 \%$ tidak berbeda nyata dengan konsentrasi $75 \%$ tetapi berbeda nyata dengan konsentrasi $0 \%, 25 \%$, dan $50 \%$.

\section{Hasil Keterampilan Proses}

Pada saat melakukan praktikum tidak mengikuti setiap proses dari awal sampai akhir dengan baik, sehingga pada saat praktikum ada bebarapa tahap yang tidak di mengerti.Anggota kelompok yang mendapat skor 2 dikarenakan dia mengikuti tahapan praktikum baik walaupun tidak fullsedangkananggota kelompok yang mendapat skor 3 dikarenakan dia mengikuti setiap proses jalannya praktikum dari awal sampai akhir dengan baik.

Berdasarkan rubrik yang telah dinilai, semua anggota kelompok rata-rata telah mampu melakukan semua langkah/proses kerja dalam penelitian dengan baik. Hal ini dapat dilihat dari rata-rata skor yang diperoleh dari setiap anggota kelompok yaitu dengan total skor 25,26 dan 27.

Anggota dengan total skor 25 berjumlah 3 orang, anggota kelompok yang memiliki total skor 26 ada 2 orang dan anggota yang kelompok yang memiliki skor 27 ada 4 orang. Memiliki total skor 27 artinya mampu melakukan proses kerja dengan sangat baik dan skor 26 artinya telah mampu melakukan proses kerja dengan baik, sedangkan skor 25 artiya mampu melakukan proses kerja dengan cukup baik namun masih terdapat beberapa kekurangan.

Terdapat 3 anggota kelompok yang mendapatkan total skor 25 yaitu Sr. Maria Theresa de Jesus Andrade, Alipia Ponsidida Dau dan Noviana Sfunit. Anggota dengan total skor 26 ada 2 orang atas nama Luisa de Marillak Yunita Dhema dan Yulia Fransina Lois Ratusehaka. Dan angggota kelompok yang memiliki skor 27 ada 4 orang yaitu Simforianus Rindo, Maria Wulandari, Skolastika Manyolita Mpamuk, Yuliana Sutanti Tallan.

Perbedaan skor ini diakibatkan karena setiap anggota kelompok ada yang belum memahami secara baik tentang prosedur kerja. Hal ini dikarenakan anggota kelompok kurang membaca, menguasai dan memahami semua petunjuk dalam proses atau langkah-langkah kerja yang diberikan. Oleh karena itu, pada saat melakukan penelitian banyak kesalahan yang dilakukan. Selain itu, kurangnya bertanya kepada anggota kelompok lain juga membuat mereka dapat melakukan kesalahan.Jadi, sebaiknya sebelum melakukan sebuah penelitian harus membaca terlebih dahulu petunjuk tentang proses kerja serta bertanyalah kepada anggota kelompok lain jika ada yang belum dipahami. 
Tabel 4. Persentase Pencapaian Tiap Aspek/Prosedur Dalam Rubrik

\begin{tabular}{|c|c|c|c|c|c|c|}
\hline \multirow{2}{*}{ No. } & \multirow{2}{*}{ Nama } & \multicolumn{5}{|c|}{ Persentase Pencapaian(\%) } \\
\hline & & P1 & $\mathbf{P} 2$ & P3 & $\mathbf{P 4}$ & P5 \\
\hline 1. & Maria Theresa de J. Andrade & 100 & 89 & 78 & 78 & 67 \\
\hline 2. & Simforianus Rindo & 100 & 89 & 78 & 89 & 67 \\
\hline 3. & Alipia Ponsidia Dau & 67 & 89 & 67 & 67 & 67 \\
\hline 4. & Skolastika Manyolita Mpamuk & 100 & 78 & 89 & 78 & 67 \\
\hline 5. & Yuliana F. Lois Ratusehaka & 100 & 78 & 78 & 67 & 100 \\
\hline 6. & Luisa de Marillak Y. Dhema & 100 & 78 & 78 & 67 & 100 \\
\hline 7. & Maria Wulandari & 100 & 78 & 67 & 78 & 67 \\
\hline 8. & Noviana Sfunit & 67 & 89 & 78 & 78 & 67 \\
\hline 9. & Yuliana Sutanti Tallan & 100 & 89 & 67 & 78 & 67 \\
\hline & TOTAL & 834 & 746 & 680 & 680 & 669 \\
\hline
\end{tabular}

Tabel 5. Persentase Kumulatif Tiap Aspek/Prosedur Dalam Rubrik

\begin{tabular}{ccccc}
\hline \multicolumn{5}{c}{ Persentase Pencapaian (\%) } \\
\hline P1 & P2 & P3 & P4 & P5 \\
92, & 84, & 75,55 & 75,5 & 74,33 \\
66 & 11 & & 5 & \\
\hline
\end{tabular}

\section{KESIMPULAN}

Berdasarkan data hasil penelitian yang dilakukan diperoleh hasil bahwa: Ekstrak rimpang Jahe (Zingiber officinale rocs, memiliki aktifitas antibakteri dalam menghambat pertumbuhan bakteri Escherichia coli secara in-vitro yang ditunjukan dengan $F_{\text {hitung }}>F_{\text {tabel }}(\mathbf{1 1 0 . 6 7 8 3 6 3}>\mathbf{7 , 5 9 )}$ yakni dengan tingkat kepercayaan $99 \%$. Ekstrak ekstrak rimpang Jahe (Zingiber officinale rocs)memiliki aktifitas antibakteri dalam menghambat bakteri Escherichia coli dengan respon hambat yang paling terbesar dan yang terbaik pada konsentrasi $100 \%$ dan mampu menghambat hingga membentuk zona hambat sebesar 18.48 $\mathrm{mm}$.

\section{DAFTAR PUSTAKA}

Ahmad, M., Cahya, A., dan Gustiar, H., 2008.Pengaruh Antioksidan Ekstrak Jahe Merah (Zingiber officinale var. Sunti) terhadap Poliferasi Sel Luekimia (THP-1), Penulisan Ilmiah, IPB (Bogor Agricultural University), Bogor.
Andini, R. D., 2008.Efek Ekstrak Jahe Merah (Zingiber officinale Roscoe.) Secara In Vitro terhadap Relaksasi Jaringan Otot Polos Trakhea Terpisah Marmut (Cavia porcellus) yang Diinduksi oleh Histamin. Skripsi, Universitas Muhammadiyah Malang, Malang.

Amir, 2009. Learning to Teach Belajar Untuk Mengajar. Yogyakarta: Pustaka Pelajar.

Alexandra Z. 2013. Biofuel Created by E. coli.

(Online). (http://impressivemagazine. com). Di akses pada 17 April 2019.

Ahmad, dkk. 2015. Eksperimentasi Model Pembelajaran Problem Based Learning (PBL) dan Kooperatif Tipe Group Investigasi (GI) Pada Materi Peluang Ditinjau Dari Kemandirian Belajar Siswa. Jurnal Elektronik Pembelajaran Matematika. 
Badan Penelitian dan Pengembangan Kementrian Pendidikan dan Kebudayaan. 2011. Survei internasional TIMSS: TIMSS (Trends in International Mathematics and Science Study). (Online) (http://litbang.kemendikbud.go.id/ind ex.php/survei-internasional-timss, diakses tanggal 15 maret 2019).

Kurniawati, 2010. Motility Test Agar. http://www.motility.html. akses (04 April 2019).

Santoso, 1994. Pengaruh Penambahan Fitobiotik Jahe Merah (Zingiber officinale Rosc) terhadap Produksi dan Profil Darah Ayam Broiler, Jurnal Protein, 2 (14).

Trianto, 2007.Pengaruh Model Problem Based Learning Dengan Metode Eksperimen Disertai Teknik Roundhouse Diagram Dan Mind Map Terhadap Hasil Belajar Biologi Ditinjau Dari Gaya Belajar Dan Motivasi Belajar Siswa. Jurnal Inkuiri.

Yanda, RF. 2014. Hubungan Pemberian Asi Eksklusif dengan Kejadian Diare Akut Di Puskesmas Pucangsawit Surakarta. (Online) (https://eprints.ac.id) Di akses pada 17 April 2019. 